\title{
Rosyjskie. Europejskie. Oświecone. Rozumne. O obecności Rosji w Azji Środkowej (i nie tylko)
}

\author{
Russian. European. Enlightened. Rational. \\ On the presence of Russia in Central Asia \\ (and not only)
}

\begin{abstract}
The author of the paper, using tools developed by postcolonial researchers, discusses the works of twentieth-century Russian writers. The setting of these texts is in the territory of Central Asia, Siberia or the Caucasus, constituting one of the factors defining them as the so-called Eastern text of Russian literature. Although most of the writers come from the other parts of Russia and - in most cases - are of Slavic descent, they know these regions quite well. These writers, however, are little interested in the problems of indigenous peoples, as long as they are not related to nationwide issues such as industrialization, collectivization or the labour camp system. The issues of destruction and loss of cultural identity, subordination, enslavement and exploitation of the local population are often omitted. The main characters in the works of Russian writers are invariably Russians, and their reference point is the Russian (Soviet) state.
\end{abstract}

Keywords: Central Asia, postcolonialism, Russian literature, colonial discourse, Yury Dombrovsky Andrzej Polak, Uniwersytet Śląski w Katowicach, Katowice - Polska, andrzejpolakus@op.pl, ORCID ID: https://orcid.org/0000-0002-3665-0115

Ważną część XX-wiecznego piśmiennictwa rosyjskiego stanowią utwory składające się na wschodni tekst literatury rosyjskiej. Opisywane w nich zdarzenia rozgrywają się na terytorium Azji Środkowej, Syberii lub Kaukazu, tj. w regionach przez dziesięciolecia wchodzących w skład imperium rosyjskiego i radzieckiego. Ich twórcy na ogół wywodzili się z innych części Rosji i mieli słowiańskie korzenie, co nie oznacza, że ziemie te były im całkowicie obce. Aleksandr Fadiejew na przykład dzieciństwo i młodość spędził na Dalekim Wschodzie, gdzie brał udział w walkach rewolucyjnych. Wsiewołod Iwanow pochodził z kazachskiego Semipałatyńska i już od wczesnej młodości zaznajomiony był z realiami 
Syberii Zachodniej. Podczas fali głodu na początku lat 20. Aleksandr Niewierow wyruszył z Powołża w poszukiwaniu żywności do Taszkientu. Boris Ławrieniow w trakcie wojny domowej walczył w Turkiestanie. Andriej Płatonow w roku 1934 przebywał na delegacji w Azji Środkowej. Konstantin Paustowski w latach 30. zwiedził rejon Morza Kaspijskiego i Gruzję, a II wojnę światową spędził w Ałma-Acie. Jurij Dombrowski na początku lat 30. został aresztowany i zesłany także do Ałma-Aty, gdzie pracował jako dziennikarz, archeolog i nauczyciel. Od roku 1950 do 1953 miejscem uwięzienia Aleksandra Sołżenicyna był łagier w północnym Kazachstanie, a pierwsze miesiące roku 1954 późniejszy laureat Nagrody Nobla spędził w szpitalu w stolicy Uzbekistanu. Matka Siergieja Borodina pochodziła z tatarskiego rodu książęcego, a sam pisarz przez wiele lat mieszkał na Dalekim Wschodzie, w Azji Środkowej i w Armenii. Isaj Kałasznikow pochodził z Buriacji. Siergiej Załygin urodził się na Uralu, a dorastał i kształcił w ałtajskim Barnaułu oraz innych regionach Syberii Zachodniej (Chakasja, Omsk). Ze Wschodniej części Syberii pochodził i był z nią związany emocjonalnie Walentin Rasputin. Wreszcie urodzony w stolicy Gruzji Aleksandr Prochanow od lat 70. jako korespondent „Literaturnoj gazety” pracował m.in. w Afganistanie.

Pisarze ci w niewielkim jednak stopniu byli zainteresowani problemami ludności tubylczej, o ile tylko nie wiązały się one ze sprawami rangi ogólnopaństwowej w rodzaju kolektywizacji [Nad Irtyszem (Ha Иpmblme, 1964) Załygina], industrializacji [Kara Bugaz (Кара-Бугаз, 1932) Paustowskiego], łagrów [Oddziat chorych na raka (Раковый корпус, 1968) Sołżenicyna], kultu jednostki [Kustosz (Хранитель древностей, 1964) Dombrowskiego], rewolucji [Ostatni z Udehe (Последний из удеге, 1929-1940) Fadiejewa, Dżan (Джан, 1970) Płatonowa, Stony parów (Солёная падb, 1967) Załygina], wojny domowej [Błękitne piaski (Голубые пески, 1923), Роwrót Buddy (Возвращение Будды, 1923) Iwanowa, Ojczulek Amиг (Амур-батюшка, 1941-1946) Nikołaja Zadornowa, Czterdziesty pierwszy (Сорок первый, 1926) Ławrieniowa] czy radzieckiej strefy wpływów [Drzewo w centrum Kabulu (Дерево в центре Кабула, 1982), Rysunki batalisty (Рисунки баталиста, 1989) Prochanowa]. Milczeniem pomijano kwestie niszczenia i utraty tożsamości kulturowej, podporządkowania, zniewolenia, eksploatacji, deterytoryzacji i dehistoryzacji, peryferyjności, traumatycznego doświadczenia reżimu radzieckiego, wypierania przez rosyjską cywilizację świata lokalnych wierzeń i obyczajów. Również powieści historyczne, w rodzaju Gwiazd nad Samarkanda Borodina czy Okrutnego wieku Kałasznikowa, ukazujące średniowieczne dzieje regionu, wyróżnia podejście zideologizowane, przeciwstawiające twórczym masom ludowym niszczycielski despotyzm okrutnych władców (Timur-Tamerlan, Dżyngis-chan).

W dziełach pisarzy rosyjskich Rosjanie obsadzani są w roli „starszych braci” ludów Azji, zobowiązanych do miłości i opieki nad „braćmi młodszymi”. Po- 
dejście to świadczy o zakładanej przez imperium rosyjskie cywilizacyjnej i nadrzędnej pozycji narodów słowiańskich wobec ludów niesłowiańskich i nieeuropejskich (muzułmańskich, żydowskich, politeistycznych). Zgodnie z dyskursem kolonialnym Rosjanie - jako rzecznicy postępu - starają się wyrwać autochtonów z odwiecznego zacofania, polegającego na przywiązaniu do przesądów i religii, nieznajomości techniki (o katastrofie przymusowej modernizacji na radzieckich peryferiach, oczywiście, się nie wspomina), braku higieny i kultury. Zapędy kolonizatorskie, zwłaszcza w okresie radzieckim, przybierają postać zakrojonych na wielką skalę projektów modernizacyjnych. W rzeczywistości było jednak inaczej. Jak zauważa Aleksandr Etkind, Rosjanie za pomocą prochu, alkoholu i roznoszonych chorób zniszczyli, wyparli lub zasymilowali liczne narody azjatyckie. Proceder ten trwał kilka stuleci (Etkind 96). Utwory rosyjskie wyróżnia ponadto nieobecność kontrdyskursu (obratnyj narrativ, counter-narrative), kontestującego apodyktyczną (meta)narrację oficjalnego kanonu. Kwestie podporządkowania, zniewolenia, eksploatacji czy degradacji kulturowej podejmowane są w nich rzadko $\mathrm{i}-\mathrm{z}$ reguły - niebezpośrednio.

Zainteresowanie Rosjan Azją zapoczątkowały wydarzenia z połowy XVI wieku, kiedy to miał miejsce podbój i przyłączenie do Moskwy chanatu kazańskiego i astrachańskiego. Państwo moskiewskie sięgnęło wówczas daleko poza etnograficzne i religijne granice Wielkiej Rosji i stanęło wobec konieczności dokonywania nowych podbojów (Heller 152). Moskwa podporządkowała swej władzy całe Powołże, a od Persji dzieliło ją tylko Morze Kaspijskie. Wkrótce rozpoczął się podbój chanatu syberyjskiego. Poszerzenie granic państwa przyniosło znaczne korzyści ekonomiczne, a car moskiewski stał się władcą ludów muzułmańskich zamieszkujących podbite tereny (Heller 153).

Powolny, lecz konsekwentny podbój Azji Środkowej rozpoczął się za Piotra Wielkiego. To właśnie od jego czasów funkcjonuje w Rosji pojęcie ucywilizowania, zakładające obowiązkową znajomość języków i kodów kulturowych Europy oraz świadomość własnej przewagi nad mniej rozwiniętymi narodami zamieszkującymi terytoria usytuowane na południe i wschód od metropolii. Piotr pragnął zanieść wschodnim narodom stojącym na „niższym” szczeblu rozwoju kulturalnego płody cywilizacji europejskiej uzyskane od Zachodu. Chciał podporządkować Rosji chanaty Chiwy i Buchary, w których planował zainstalować rosyjskie oddziały wojskowe w charakterze gwardii chanów. Pierwsze próby nie były jednak udane. Wyprawa księcia Aleksandra Bekowicza-Czerkasskiego na Chiwę w roku 1717 zakończyła się katastrofą (Heller 355). W XVIII stuleciu piśmiennictwo rosyjskie, dzięki przekładom na języki zachodnie, dołączyło do dyskursu orientalnego, zasadzającego się na opozycji Wschodu i Zachodu, gdzie Zachód uznawany był za ostoję cywilizacji otoczoną przez morze barbarzyńców, których należy podbić, narzucając im normy moralne i kulturowe. W wieku XIX zaczął 
się kształtować złożony, wielowymiarowy dyskurs, który można nazwać „rosyjskim orientalizmem" - zjawisko odrębne, choć silnie związane z ukształtowanym w epoce oświecenia orientalizmem zachodnim (Alekseev). Poszerzanie terytorium imperium rosyjskiego thumaczono troską o zapewnienie bezpieczeństwa, poszukiwaniem niezawodnych granic, najlepiej naturalnych (Heller 384). Polityka ta spowodowała przyłączenie do Rosji pomiędzy rokiem 1858 a 1881 m.in. Kraju Amurskiego, Wschodniego i Zachodniego Kaukazu, Taszkientu, Samarkandy, Buchary, Chiwy, Kokandu i Geog-Tepe. Podbój tych obszarów przyspieszyły niepowodzenia w wojnie krymskiej, skutkiem której uwaga zwolenników polityki ekspansjonistycznej skupiła się na kierunku środkowoazjatyckim. Ekspansja państwa rosyjskiego miała dwie przyczyny: polityczną - chodziło o przeciwstawienie się planom Wielkiej Brytanii w Azji i ekonomiczną - miała służyć wspieraniu interesów rozwijającego się rosyjskiego przemysłu i handlu (Heller 621).

Sytuacja podbitych przez Rosjan terytoriów w Azji Środkowej zmieniła się po rewolucjach roku 1917, kiedy to na ziemiach nierosyjskich zaznaczył się wzrost nastrojów niepodległościowych. Dla Kazachów i Kirgizów koloniści rosyjscy, którzy zajęli ich pastwiska, byli nie tyle wrogami klasowymi, ile etnicznymi. Podejmowane wówczas przez narody zamieszkujące centralną część Azji próby uzyskania samodzielności zakończyły się jednak niepowodzeniem. W latach 1918-1919 Azja Środkowa stała się widownią gwałtownych starć, w czasie których konflikty społeczne („klasowe”) były wyrazem przede wszystkim nienawiści narodowej, a nawet rasowej (Pipes 157). Nieprzypadkowo komunistyczny historyk Grigorij Safarow nazwał wydarzenia w Turkiestanie (1917-1918) rewolucją kolonialną. Pomysł autonomii Turkiestanu został odrzucony, a muzułmanom stanowiącym 97\% ludności odmówiono prawa do zasiadania w organach władzy sowieckiej. Na skutek podejmowanych przez nowe władze praktyk kolonialnych nieliczna mniejszość rosyjska zdominowała ludność tubylczą i wykluczyła ją z udziału w rządzeniu. Komunistyczny historyk i świadek wydarzeń nie zawahał się nazwać ten reżim „feudalnym wyzyskiem szerokich mas rdzennej ludności przez rosyjskiego czerwonoarmistę, kolonistę i urzędnika" (Pipes 166).

Co ciekawe, ani w Rosji carskiej, ani w Rosji radzieckiej podbitych terytoriów nigdy nie nazywano koloniami. Chociaż propozycje takie się pojawiały, to skazane były na niepowodzenie. W wieku XIX część działaczy państwowych zamierzała wprowadzić w imperium rosyjskim pojęcie kolonii. W roku 1873 general-gubernator Turkiestanu Konstantin von Kaufman w projekcie Položeniâ ob upravlenii Turkestanskogo kraâ porównał rosyjskie posiadłości w Azji do Indii Brytyjskich i zaproponował, aby zarządzać nimi jak koloniami, co spotkało się z odmową ministra wojny Dmitrija Milutina (Hodarkovskij 109). Obszar rosyjskiej kolonizacji poszerzał się wraz z rozwojem terytorialnym państwa. Terenom kolonizowanym nadawano szczególny status, należały one jednak bezpośrednio do Rosji, skut- 
kiem czego władze nie czuły potrzeby stosowania podziału na kolonie i metropolię (Etkind 100). Był to rzadki przypadek kolonializmu bez kolonii. Tymczasem rozwój modelu kolonialnego w azjatyckiej części imperium niewiele odbiegał od modelu francuskiego, hiszpańskiego, portugalskiego i niemieckiego, tj. państw, które bezpośrednio zarządzały koloniami. Różnica polegała na tym, że Rosjanie uparcie odmawiali uznania faktu posiadania kolonii; przyłączane nowe terytoria i narody niemal natychmiast uznawano za nieodłączną część państwa rosyjskiego (Hodarkovskij 111). Także propaganda radziecka unikała określania stosowanych praktyk mianem kolonizacji. Pośród opozycji o „kolonizacji radzieckiej” mówili tylko radykalni nacjonaliści w republikach radzieckich. Nawet dysydenci terminologię tę uznawali za zbyt radykalną. W rezultacie krytyka radzieckiej polityki eksploatacji i akulturacji korzystała z innych, niezwiązanych z kolonizacją pojęć (Kukulin).

Chociaż wydarzenia opisywane w utworach Dombrowskiego, Sołżenicyna czy Fadiejewa rozgrywają się w Azji Środkowej, to ich bohaterami są niemal wyłącznie Rosjanie, a punktem odniesienia państwo rosyjskie, nigdy zaś peryferyjny Kazachstan czy Uzbekistan. Azja Środkowa konsekwentnie prezentowana jest jako terytorium rosyjskie, a doświadczenia postaci są doświadczeniami rosyjskimi, zanurzonymi w kulturze i historii Rosji. Dzieje i tradycje świata muzułmańskiego są wyparte lub marginalizowane, ludność tubylcza jest milcząca i bezimienna. Dotyczy to nawet tych tekstów, które, jak Kustosz Dombrowskiego, wydają się wolne od retorycznych rozwiązań udzielających wsparcia imperialnym wysiłkom Rosjan, ukazanych jako ludzie zatroskani rozwojem zapóźnionych regionów. Wypowiedzi poświadczające, że skolonizowani w niczym nie ustępują kolonizatorom, są rzadkie. Jak zauważa główny bohater powieści Dombrowskiego:

[...] Przed dwoma laty pojechałem służbowo do pewnego stepowego sowchozu w partyjnej sprawie. Wspaniały sowchoz. Nie da się ukryć. Doskonale zorganizowany, rentowny... Step, a wszędzie ogrody, ogródki, zieleń, szkoła średnia, piętrowy klub. Dyrektor to rdzenny mieszkaniec tej ziemi. I trzyma się jej zębami (Dombrowski 173-174).

Nawet w takich przypadkach uwaga skupia się jednak na osobach popierających władze radzieckie. Główny bohater Kustosza wspomina o działaczu politycznym kazachskiego pochodzenia, który wsławił się odwagą podczas rewolucji, był przyjacielem Kujbyszewa i ma „niemal rosyjskie nazwisko”, co czyni zeń typową kolonialną hybrydę. Skutkiem praktyk kolonialnych jest bowiem kształtowanie się tożsamości hybrydowej. Mieszkańcy kolonii muszą postrzegać i oceniać samych siebie zarówno „od wewnątrz”, jak i „,z zewnątrz”, z punktu widzenia i wartości kolonizatorów (Kukulin). Postawa działacza, świadcząca o częściowej identyfikacji z kulturą najeźdźców, odsyła nie tylko do kategorii hybrydowości, 
ale także implementacji przez narody skolonizowane kultury kolonizatorów i dostosowaniu uniwersalnej jakoby misji historycznej do warunków lokalnych. Jasny podział na kolonizatorów i kolonizowanych zaciera się. Powieść Dombrowskiego, jak wiele innych, sugeruje centralny charakter kultury rosyjskiej w tym regionie.

Twórcy literatury rosyjskiej świadomie wprowadzają postacie wyedukowanych, kulturalnych krajowców, których postawa ma poświadczać wyższość kultury rosyjskiej. Osoby te wyróżnia rozmyte, hybrydowe poczucie przynależności narodowej, spowodowane charakterystyczną dla kolonializmu państwowego metodą zarządzania, w której Rosja wyprzedziła pozostałe mocarstwa europejskie. W roku 1835 angielski historyk Thomas Macauley wzywał do utworzenia w Indiach klasy rządzącej, której członkowie byliby „Hindusami z krwi i koloru skóry, ale Anglikami ze względu na gusta, intelekt i wartości moralne". Tymczasem podobna klasa pośredników, od dawna obeznanych z kulturą rosyjską, pomagała Rosji władać podbitą ludnością. Od końca wieku XVIII synów znaczących przedstawicieli skolonizowanych narodów wysyłano po naukę do rosyjskich szkół elitarnych. Po powrocie przewodzili oni swoim narodom z korzyścią dla imperium (Hodarkovskij 113).

Pisarze rosyjscy mniej lub bardziej intencjonalnie wpisują dzieje Azji Środkowej w historię Rosji i jednocześnie wymazują doświadczenia ludów podbitych. Proceder ten Edward Said nazwał strategią zawłaszczania kulturowego, tylko bowiem opowieść zdobywcy warta jest opowiedzenia, skolonizowani muszą zaś pozostać głusi i niemi kulturowo (Thompson 172). Zgodnie z sugestią zawartą w piśmiennictwie rosyjskim to właśnie Rosjanie wprowadzili w azjatyckiej dziczy wszelkie udogodnienia cywilizacyjne. Ziemie te i ich mieszkańcy wydają się wręcz pożądać rosyjskiej obecności, pomocy i kultury. Jak pisze Ewa Thompson, już Nikołaj Karamzin w Historii państwa rosyjskiego utrzymywał, że Moskwa zdołała poszerzyć swe dominia dzięki wpływowi moralnemu, a nie dzięki sile armii. Mit pokojowej ekspansji Rosji obecny jest w wielu tekstach współczesnej literatury rosyjskiej (Thompson 177). Tymczasem, zdaniem badaczki, skutkiem rosyjskiego panowania w Azji Środkowej stało się spustoszenie i regres cywilizacyjny (Thompson 183). Opinia ta jest sprzeczna z fundamentalnym dla dyskursu kolonialnego binarnym podziałem na „cywilizację” i „barbarzyństwo”, gdyż Rosja uznana zostaje za barbarzyńską nie tylko wobec Zachodu, ale również Wschodu.

Przedstawiciele XX-wiecznej literatury rosyjskiej pełną garścią czerpią z retorycznych rozwiązań typowych dla narracji kolonialnej. Jak zauważa Ilja Kukulin, w nieoficjalnej kulturze rosyjskiej i w kulturze narodów radzieckich świadomość postkolonialna zaczęła się kształtować dopiero w latach 60. Stało się tak, ponieważ ZSRR od samego początku uchodził za „imperium działań pozytywnych” (imperiâ utverždâ̂sego dejstviâ, wyrażenie Terry'ego Martina). W pierwszym 
dziesięcioleciu po rewolucji na poziomie propagandy i taktyki władze radzieckie uznawały mniejszości narodowe za ,już zdekolonizowane”, jednakże na poziomie administracyjnym i w perspektywie strategicznej ustanawiały nowy, nieoficjalny reżim kolonialny, wspierany przez probolszewickie elity miejscowe. Podejmowane w tym czasie przez władze lokalne nieśmiałe próby prowadzenia prawdziwej polityki antykolonialnej spotykały się ze zdecydowanym sprzeciwem władz centralnych. Proceder, polegający na przechwytywaniu haseł antyimperialnych i prezentowaniu ich jako polityki nowego rządu, Kukulin nazywa kolonializmem utopijnym. W latach 30. XX wieku państwo radzieckie zarzuciło koncepcję imperium działań pozytywnych i zastąpiło ją programem nazwanym przez Davida Brandenbergera narodowym bolszewizmem (wcześniej terminem tym posłużył się Michaił Agurski, odnosząc go do światopoglądu charakterystycznego dla małych grup przywódców partyjnych i inteligencji). Brandenberger narodowy bolszewizm uznał za zjawisko społeczne o szerszym wymiarze - odmianę zideologizowanej kultury masowej, propagowanej w latach 30. Naród rosyjski obwołany został ,starszym bratem”, podstawowym i państwotwórczym etnosem radzieckim (Kukulin).

Z końcem epoki stalinowskiej narodowy bolszewizm zniknął z przestrzeni publicznej. Nie zastąpiła go jednak żadna inna ideologia. W czasach Breżniewa radziecką politykę narodową cechowało podejście pragmatyczne, nastawione na rozwiązywanie zadań taktycznych i podtrzymywanie kruchego spokoju społecznego. Ważnym aspektem tej postutopijnej sytuacji była powszechna, dotycząca zarówno władz, jak i społeczeństwa pamięć o katastrofalnej przemocy lat 30. i 40. - Wielkim Terrorze, deportacji narodów, II wojnie światowej. Erozja ideologii kolonialnej i strach przed nowymi represjami spowodowały ważne następstwa kulturowe. Próby opisania skutków polityki narodowościowej (nacional'noe stroitel'stvo) i transformacji samoświadomości narodów radzieckich doprowadziły do uznania świadomości człowieka radzieckiego za hybrydową, łączącą wzajemnie sprzeczne cechy osoby „,sprawującej rządy” i „rządzonej”. Po rozpadzie ZSRR w literaturze rosyjskiej i literaturach byłych republik radzieckich przejawy świadomości postkolonialnej stały się bardziej widoczne. Według Kukulina w latach 1960-1980 w części literatur radzieckich ukształtowało się ,postkolonialne pismo w sobie", w latach 90. i na początkach nowego stulecia zaś ,postkolonialne pismo dla siebie" (Kukulin). Rozpad ZSRR spowodował ponadto pośmiertny żywot kultury radzieckiej.

Inną ważną kwestię stanowi zacieranie się granic pomiędzy Rosją a rosyjskim Orientem. $Z$ tego powodu miejsce Orientu w obrębie kultury rosyjskiej jest nieokreślone. Trudno rozstrzygnąć, czy pewne terytoria wraz z zamieszkującą je ludnością są jeszcze Rosją, czy już nie. W wieku XIX kolonizacja Powołża, Uralu i Syberii stała się domeną przeszłości i podlegała polityce wewnętrznej. 
Zmieniały się granice oddzielające „swoich” od „obcych”. Kolonizacja sąsiedniego „obcego" powodowała, że zyskiwał on status „swojego”. Proces ten nie zawsze oznaczał rusyfikację kolonii - niekiedy sami Rosjanie chętnie naśladowali mieszkańców podbitych lub przyłączonych obszarów. Nacjonalizacja nowego „swojego” wymagała jednak kolonizacji kolejnych „obcych”. W rezultacie granice Rosji zmieniały się nieustannie i były dziełem fantazji. Wierzono powszechnie, że konieczność ustanowienia nowych granic podyktowana jest wymogami bezpieczeństwa imperium i jego mieszkańców. Wraz ze wzrostem terytorialnym imperium rozszerzały się także granice kultury rosyjskiej. Rosja była więc nie tyle terytorium realnym, ile dziedziną „geografii wyobrażonej”. Przekonanie o zmienności i wyobrażeniowym charakterze granic w znacznej mierze wynikało z kompleksów Rosjan wobec Europy. Rosja była bowiem Europą z perspektywy Azji, ale Azją z perspektywy Europy (Norimatsu 299). Niemniej jednak zacofanie Rosji wydaje się względne. Na przestrzeni wieków państwo rosyjskie odstawało od Europy niemal pod każdym względem - handlu, nauki, ekonomii, wojskowości czy spraw religii. Dotyczy to jednak, twierdzi Michael Chodarkowski, przede wszystkim społeczeństwa. Trudniej natomiast dowodzić zacofania rosyjskiego aparatu państwowego. To właśnie nadmierna rola rządu w historii państwa stała się głównym czynnikiem odróżniającym Rosję od pozostałych imperiów europejskich (Hodarkovskij 105).

Współczesnych Rosjan cechuje ograniczona wiedza na temat literatury i kultury państw Azji Środkowej. Zdaniem Władimira Miedwiediewa, Azja Środkowa dla większości Rosjan była i nadal pozostaje ,ziemią nieznaną”. Pierwsze utwory literatury rosyjskiej poświęcone temu regionowi powstały dopiero w czasach radzieckich. Były to Gwiazdy nad Samarkanda (3везды над Самаркандом, 1953-1973) Siergieja Borodina, Człowiek zmienia skórę (Человек меняет кожу, 1933-1934) Brunona Jasieńskiego, Nisso (Hиссо, 1946) Pawła Łukinckiego. Obecnie czytelnicy znają, co najwyżej, Opowieść o Hodży Nasreddinie (Повесть о Ходже Насреддине, I część 1940, II część 1950, opublikowane w ZSRR w 1956 roku) Leonida Sołowjowa. Najważniejsze współczesne rosyjskie utwory poświęcone Azji Środkowej to Chorramabad (Хуррамабад, 2000) i Powrót do Pandżurudu (Возвращение в Панджруд, 2013) Andrieja Wołosa, Powieść taszkiencka (Ташкентский роман, 2006) Suchbata Afłatuni (Jewgienij Abdullajew), Przektad z notatnika (Перевод с подстрочника, 2013) Jewgienija Czyżowa (Aziâ ušla ot nas nepoznannoj: interv'ûs Vladimirom Medvedevym, źródło elektroniczne). Tymczasem wkładu narodów środkowoazjatyckich w kulturę światową nie sposób przecenić. W wiekach średnich tutejsza literatura i jej wybitni przedstawiciele - Rudaki, Aliszer Nawoi czy Dżami - stanowili część świata arabsko- i perskojęzycznej kultury wysokiej. W XVIII i XIX stuleciu w Azji Środkowej zaczęły powstawać narodowe szkoły literackie, literatura była wówczas 
nieodłączną częścią kultury islamu. Na poetykę i metaforykę środkowoazjatyckich utworów wpływ miała religia, częste były odwołania do Proroka i Koranu. W pierwszej kolejności rozwijała się poezja, stanowiąca najwyższe osiągnięcie kultury perskiej i tureckiej tamtych czasów.

Rozwój sztuk został zahamowany w połowie XIX wieku, kiedy to Azją Centralną zainteresowały się imperia rosyjskie i brytyjskie. Pod ich naciskiem miejscowe reżimy utraciły niezależność. Był to nie tylko kryzys polityczny, ale także kulturalny. W kolejnym stuleciu region zaczął podlegać globalizacji. Miejscowe elity, w odróżnieniu od lepiej obeznanego z Europą Imperium Osmanów, nie były przygotowane na postęp i ekspansję kultury zachodniej. Azja Środkowa doświadczyła ponadto niepoddającej się prostym ocenom sowietyzacji. Chociaż podniósł się ogólny poziom wykształcenia, to rozwój kultur narodowych był hamowany przez władze centralne - wspieranie tradycji narodowych oraz zainteresowanie własną historią Moskwa uznawała za niebezpieczny nacjonalizm, prowadzący do separatyzmu. Mimo to w okresie radzieckim pojawiło się wielu interesujących twórców, takich jak Abdiżamil Nurpeisow, Czyngiz Ajtmatow, Szamszad Abdullajew, Muhammad Salih czy jawnie opozycyjna Annasoltan Kiekiłowa. Położenie miejscowych dysydentów było dużo gorsze niż dysydentów rosyjskich. Ci drudzy mogli bowiem liczyć na międzynarodowy rozgłos, podczas gdy opozycjonistom środkowoazjatyckim uzyskać takie wsparcie było dużo trudniej (Vereskov).

Po rozpadzie ZSRR państwa Azji Środkowej doświadczyły licznych kryzysów politycznych i gospodarczych. Do władzy doszły reżimy autorytarne. Wyjątek stanowi Kazachstan oraz - w pewnym stopniu - Kirgizja. Trudna sytuacja panuje w Tadżykistanie, gdzie w zasadzie jedynym publikowanym ,pisarzem” jest prezydent państwa Emomali Rachmon. Nie lepiej dzieje się w Turkmenistanie, Uzbekistanie i Kirgizji. Pisarze tworzący w miejscowych językach narodowych praktycznie pozbawieni są czytelników. W całej Kirgizji, którą zamieszkuje ponad sześć milionów mieszkańców, funkcjonuje zaledwie ok. dwudziestu księgarni. Lekceważący stosunek do kultury przy równoczesnym ograniczaniu swobód politycznych powoduje, że od lat 90 . XX wieku trwa emigracja pisarzy środkowoazjatyckich do Europy Zachodniej. Nakłady ich książek są tam jednak niewielkie i przypominają radziecki samizdat (Vereskov). Trudno rozstrzygnąć, w jakiej mierze zaistniała sytuacja ma związek z długą przynależnością regionu do Rosji i ZSRR, co dowodzi potrzeby łączenia badań postkolonialnych z postradzieckimi. Na związek ten wskazuje Thompson, wedle której redukcja i eliminacja środkowoazjatyckich elit w latach 20. ubiegłego wieku stała się gwarancją, że azjatyckie kolonie Rosji nie prędko przemówią własnym słyszalnym głosem (Thompson 186). W stwierdzeniu tym jest sporo racji, tym bardziej że część państw tego regionu nadal pozostaje uzależniona od Rosji, co świadczy o ich postkolonialności. Termin ten, w odróżnieniu od węziej rozumianego postkolonializmu, akcentuje 
wymiar psychologiczny i mentalny. Jeśli autorefleksja kolonizatorów stanowi cechę szczególną świadomości europejskiej, która objawia się nienawiścią do samych siebie, to w Rosji świadomość taka jest zjawiskiem rzadkim, w przestrzeni publicznej wręcz nieobecnym.

\section{Bibliografia}

Alekseev, Pavel Viktorovič. Russkij obraz Vostoka kak problema postkolonial'noj kritiki. Web. 16.04.2019. https://studfiles.net/preview/8118552/.

Aziâ ušla ot nas nepoznannoj: interv'û s Vladimirom Medvedevym. Web. 11.05.2019. http://www. ca-portal.ru/article: 44180 .

Dombrowski, Jurij. Kustosz. Przeł. Ignacy Szenfeld. Warszawa, Czytelnik, 1987.

Ètkind, Aleksandr. Vnutrennââ kolonizaciâ. Imperskij opyt Rossii. Moskva, Novoe literaturnoe obozrenie, 2013.

Heller, Michaił. Historia Imperium Rosyjskiego. Przeł. Eugeniusz Mielech i Tadeusz Kaczmarek. Warszawa, Książka i Wiedza, 2002.

Hodarkovskij, Majkl. „V čem Rossiâ «operežala» Evropu, ili Rossiâ kak kolonial'nâ̂ imperia”. Tam, vnutri. Praktiki vnutrennej kolonizacii v kul'turnoj istorii Rossii. Red. Aleksandr Ètkind, Dirk Uffel'mann, Ilja Kukulin. Moskva, Novoe literaturnoe obozrenie, 2012, s. 105-116.

Kukulin, Il'â. «Vnutrennââ postkolonizaciâ»: formirovanie postkolonial'nogo soznaniâ v russkoj literature 1970-2000. Web. 21.06.2019. http://gefter.ru/archive/11708.

Norimacu, Këhèj. „Problema granicy “Rossii»v kavkazskih tekstah russkogo romantizma”. Tam, vnutri. Praktiki vnutrennej kolonizacii v kul'turnoj istorii Rossii. Red. Aleksandr Ėtkind, Dirk Uffel'mann, Ilja Kukulin. Moskva, Novoe literaturnoe obozrenie, 2012, s. 284-310.

Pipes, Richard. Rosja bolszewików. Przeł. Władysław Jeżewski. Warszawa, Wydawnictwo Magnum, 2005.

Thompson, Ewa. Trubadurzy Imperium. Literatura rosyjska i kolonializm. Przeł. Anna Sierszulska. Kraków, Universitas, 2000.

Vereskov, Sergej. V kraû hlopka i krovi: čto nado znat' o literature Srednej Azii. Web. 26.07.2019. https://knife.media/uzbek-writers/. 